\title{
Ekko, echo og ecco
}

Mange pasienter henvises til «ecco-undersøkelse». Det er hinsides enhver logikk.

Bilyder over prekordiet er meget vanlig hos barn, og for primærleger kan det være vanskelig å skille mellom fysiologiske og patologiske bilyder. Tallrike er derfor henvisningene til barnekardiologiske instanser om utredning.

Påfallende mange av disse henvisningene lyder «Henvises til ecco-undersøkelse». Når jeg får en slik henvendelse, gjør jeg som jeg blir bedt om: Jeg undersøker skoene til pasienten.

Ekkokardiografi er et tungt og vanskelig ord, og det blir naturlig nok i dagligtale forkortet til ekko, både muntlig og skriftlig. Med de mange anglisismer vi har i vår faglige språkbruk kan det vel til nød være akseptabelt å skrive dette på engelsk, altså echo. Echo er for øvrig også den latinske skrivemåten for lydfenomenet ekko.

Å skrive ecco, derimot, er hinsides enhver logikk. Det er verken norsk, engelsk, gresk eller latin. Og etter å ha sjekket en lang rekke språk har jeg fremdeles ikke funnet ett eneste der skrivemåten er ecco. Så hvorfor ikke bruke det gode norske ekko?

Et fagmedisinsk tillegg: $\AA$ henvise til ekkoundersøkelse er feil! Når det gjelder barn der det er spørsmål om hjertefeil, skal de henvises til hjerteundersøkelse. I begrepet «hjerteundersøkelse» inngår mange elementer, så som anamnese, auskultasjon, palpering av pulser, vurdering av svikttegn, respirasjonsmønster, hudfarge, $\mathrm{O}_{2}$-metning, blodtrykk, EKG osv. Ofte, men ikke nødvendigvis alltid, inngår også ekko.

\section{Petter S. Hagemo}

pshagemo@broadpark.no

Petter S. Hagemo (f. 1943) er spesialist i barnesykdommer og tidligere overlege ved Barnehjerteseksjonen, Rikshospitalet.

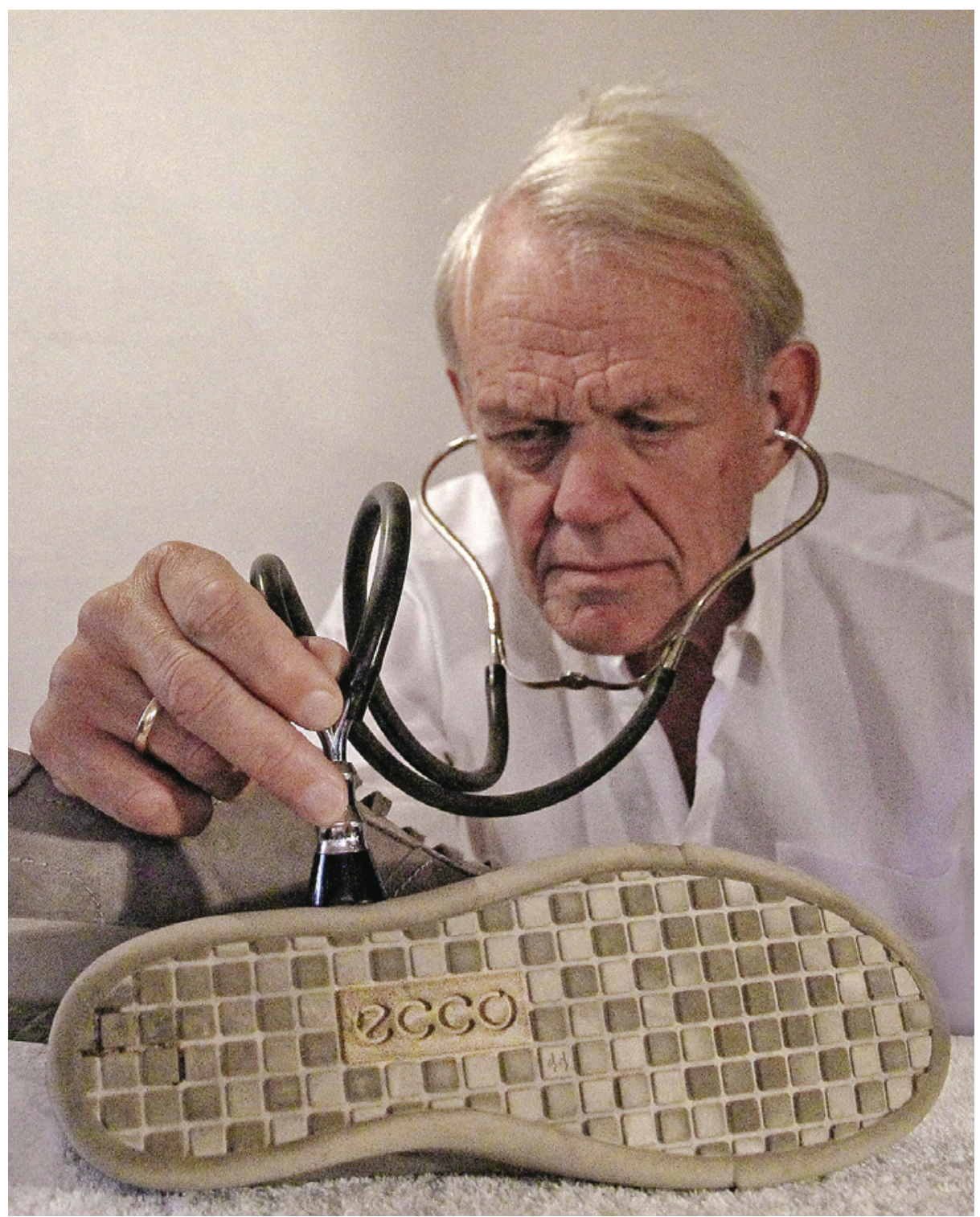

Nårjeg møter en pasient som er henvist til «ecco-undersøkelse», gjør jeg som jeg blir bedt om - jeg undersøker pasientens sko. Foto: Privat 